UDK 341.981:347.6

347.6(497.7):341.981

Original scientific article

\title{
SPECIALIZATION OF JURISDICTION BACK FROM OBLIVION - A NEW ATTENTIVE AND ASSIDOUS APPROACH TO COMPLEX CROSS BORDER FAMILY LAW CASES OR POSSIBLE REVITALIZATION OF 'MUTUAL TRUST'
}

\author{
Milka Rakočević, PhD, Associate professor \\ University Ss. Cyril and Methodius, Faculty of Law "Iustinianus Primus"- Skopje \\ Blvd. Goce Delčev 9, 1000 Skopje, N. Macedonia \\ m.rakocevic@pf.ukim.edu.mk
}

\section{Ilija Rumenov, PhD, Assistant professor}

University Ss. Cyril and Methodius, Faculty of Law "Iustinianus Primus"- Skopje Blvd. Goce Delčev 9, 1000 Skopje, N. Macedonia

i.rumenov@pf.ukim.edu.mk

\begin{abstract}
New trend emerges in the quest for establishing real actual trust between the main stakeholders in the complex cross border family law cases, which is providing for concentration of jurisdiction. The Hague Conference of Private International Law (HCCH) and the European Union $(E U)$ are in forefront of establishing concentrating jurisdiction for those proceedings based on limitation of the number of courts in order to solve two problems: to enhance the predictability and the uniformity of the outcomes in these cases and to re-establish the mutual trust on realistic grounds instead of its current notion as a political decision. Such strategy is welcomed since it starts from the bottom and it tends to elevate the trust between the persons concerned in these proceedings and with that it stretches its prerogatives to the top, which is to enhance the trust between the legal systems. Whether it will succeed it depends again on the modalities of its establishment in the national legal systems.

Generally, specialization of jurisdiction is frequently considered to be an important reform initiative in improving the development of a successful judicial system which is why it is recognized as a rapidly growing trend regarding the organization of the judiciary systems worldwide. The article will discuss the concepts of specialization of jurisdiction and its possible implementation in the national legal system of Republic of North Macedonia (N. Macedonia) regarding the complex cross border family law cases.
\end{abstract}

Key words: concentration of jurisdiction, cross border family law cases, judicial specialization, specialized courts and divisions. 


\section{INTRODUCTORY REMARKS}

Judicial specialization is frequently recognized as a key reform initiative in enhancing the development of a successful judicial system since it can play a significant role in improving the efficiency and quality of justice. Due to such perception, in recent years it is identified as a rapidly growing trend regarding the organization of the judiciary systems worldwide.

In general, the concept of specialization suggests division of work in number of different spheres, which should be entrusted to different institutions and actors who possess special skills or knowledge required to handle specific matters in each particular field that requires such expertise. ${ }^{1}$ In the context of making the judicial organization compatible with the requirements of expertise, specialization is commonly considered as a tool to ensure that judges have the knowledge and skills required to do their job in a timely and correct manner. ${ }^{2}$ In terms of specialization on the basis of the type of work they do, it is assumed that all adjudicators are specialized in judging. ${ }^{3}$

Judicial specialization can take different forms. In the legal theory there are different approaches in defining the forms of judicial specialization. For instance, distinctions are made between: 1 . long-term and short-term specialization; 2. fulltime and part-time specialization; 3 . distinction regarding the extensiveness of the cases handled by the specialized court; and 4. specialization regarding criminal law. ${ }^{4}$ On the other hand, judicial specialization can be classified in different organizational forms as well. In that regard, we can speak about jurisdictional specialization, as the most typical form of specialization which implies division of work between several branches of jurisdiction that have separate appellate instances and

Uzelac A., Mixed Blessing of Judicial Specialsation: The Devil is in the Detail, Russian Law Journal, Vol. II, Issue 4, 2014, p. 148.

2 Mak E., Balancing Territoriality and Functionality; Specialization as a Tool for Reforming Jurisdiction in the Netherlands, France and Germany, International Journal for Court Administration, Vol. 1, Issue 2, October 2008, p. 1.

3 In general, all judges are specialized simply by doing the job of a judge. Baum L., Judicial Specialization and the Adjudication of Immigration Cases, 59(8) Duke Law Journal 1501, 2010, p. 1531.

4 Distinction between long-term and short-term specialization is made depending on whether the judges have permanent assignments to particular type of cases, or they are assigned to particular types of cases for specified or unspecified periods, moving from one subject matter to another over time. Fulltime and part-time specialization refers to whether the judges focus on a single type of cases or move back and forth between a broad docket and a narrower one. The third distinction concerns the breadth of cases that a specialized court or a unit of that court hears and in that regard the extensiveness of a judge's specialized field. The specialization regarding criminal law implies that in this field, specialization is not based only on subject matter of the case, but also by defendant type. For further details, see Baum L., Probing Effects of Judicial Specialization, 58(7) Duke Law Journal 1667, 2009, p. 1673-1675. 
form a separate pyramid of hierarchical institutions (specialization of court structures), and several other categories of specialisation, such as internal specialization, personal specialization and procedural specialization. ${ }^{5}$

Judicial specialization can be interpreted from different perspectives. Commonly, it is anticipated as specialization in terms of case type or type of disputes handled by the judge. In that regard, distinction is being made between "generalist" judges and "specialist" judges, those handling wide range of cases as opposed to those who hear narrow range of cases. ${ }^{6}$ Subject matter specialization can be defined in terms of cases as well as judges. Specialization by judges concerns the extent to which judges focus on narrow sets of cases. That is the more common dimension. The other dimension of subject matter specialization is the concentration of cases, which concerns the extent to which a particular type of case is decided by a narrow set of judges. ${ }^{7}$ Referring to the specialization in this context, the concept of concentration of cases as a particular form of specialization is defined as mechanism through which one or more courts in specific territories have exclusive competence to deal with certain categories of cases. ${ }^{8}$ In that regard, the frequently mentioned notion of concentration of jurisdiction implies that within particular national jurisdiction, only certain court or limited number of courts are allocated to handle specific and distinct legal issues. ${ }^{9}$

5 The internal specialization refers to division of labor in the particular court with distribution of the cases to "specialized" unit or division within the court made internally. Since the possibility of engagement of specialized judges may be provided within a "specialized" court but also within a separate division or unit within the "generalist" courts, the distribution of cases in the particular court, although invisible for the court users, will be done internally. The personal specialization is related to distribution of cases to single judges taking into account their different skills, approaches and competences. The procedural specialization appears when special procedures apply when dealing with "special" type of cases, i.e. when different methods are prescribed or regulated by law for handling different cases. See Uzelac, op. cit., note 1, p. 148-149.

6 The Consultative Council of European Judges (CCJE), uses the term "specialist judge" to imply a judge who deals with limited areas of the law (e.g. criminal law, tax law, family law, economic and financial law, intellectual property law, competition law) or who deals with cases concerning particular factual situations in specific areas (e.g. those relating to social, economic or family law). Para 5 of the Opinion (2012) no. 15 of the CCJE on the Specialisation of Judges adopted at the 13th plenary meeting of the CCJE (Paris, 5-6 November 2012).

7 See Baum L., Judicial Specialization, Litigant Influence, and Substantive Policy: The Court of Customs and Patent Appeals, 11 Law \& Society Review 823, 1977, p. 826-827.

$8 \quad$ Mak ,op. cit., note 2, p. 2.

9 Concentration of cases within particular national jurisdiction can be achieved through different models. The basic organizational scheme can be shaped so that concentration of cases either falls within the jurisdiction of a court of higher level (appellate court); the jurisdiction of specialized courts; or within jurisdiction of one or several first instance courts. On models of concentration of jurisdiction in cross-border family matters see Župan M.; Poretti P., Concentration of Jurisdiction in Cross-Border Fam- 
Regarding specialization through concentration, in recent years it can be noticed that reforms that are undertaken concerning the organization of the judiciary shift the focus to an organizational standard based on functionality rather than upholding to the traditional standard based on territoriality in order to make the judicial organization more compatible with the requirements of expertise. In that respect, the allocation of jurisdiction based on subject matter is being highlighted. ${ }^{10}$

\section{PRO ET CON OF JUDICIAL SPECIALIZATION - IS SPECIALIZATION OF JUDGES PREFERABLE IN THE CONTEXT OF PROMOTING THE PROPER ADMINISTRATION OF JUSTICE?}

It can be noticed that the extent and degree of judicial specialization increases over time due to the fact that the law is becoming more complex and specific in certain fields. When opting for certain reforms that will improve the organizational structure of judiciary in order to achieve a pleasing level of quality regarding the proper administration of justice, the policymakers typically recognize the concept of judicial specialization as desirable and attractive. Still, even though several desirable objectives can be achieved with its promotion, it shouldn't be a priori identified as something that always brings positive results. Along with the advantages, certain issues arise as drawbacks meaning that judicial specialisation in certain aspects can produce negative effects as well. ${ }^{11}$

The proponents of judicial specialization emphasize three main advantages of specialization of judges: 1 . higher quality in decision making; 2 . consistency and coherence of case law resulting in enhanced legal certainty; and 3. greater efficiency and improvement of case management of the court.

Generalist judges sometimes are referred to as novices at everything and experts to nothing. ${ }^{12}$ In-depth knowledge and greater expertise in certain legal field is always

ily Matters - Child Abduction Cases in Vinković M. (ed.), New Developments in EU Labour, equality and human rights law, Pravni fakultet Osjek, 2015, p. 344.

10 Mak, op. cit., note 2, p. 1.

11 If we look at the big picture, discussions over pluses and minuses of judicial specialization and the existing trend towards specialized judiciary in many national legal systems may imply that specialization of judges has more positive than negative effect on the functioning of the system of administration of justice. Yet, this postulation should be taken cautiously when reaching conclusions about the desirability of judicial specialization since there are limited information that exist on its impact. Few empirical studies in that regard have been carried so the empirical evidence on the impact of specialization is limited. Baum, op. cit., note 4, p. 1680-1681.

12 Generalist judges work on a broad array of legal areas all typically but master none, thereby producing decisions that, because they do not reflect in-depth expertise, run the risk of being lower in quality. 
desirable since it is likely to produce higher quality decisions especially in complex areas of the law. It is assumed that specialist judge with greater expertise in his specific field can have greater impact on enhancing the authority of the court as well. ${ }^{13}$ The concentrated jurisdiction over certain type of cases along with the higher quality of decision making leads to enhancing the uniformity and consistency in applying the law in certain areas when the dispute settlement is in the competence of a specialist judge. That contributes to greater predictability and builds the public confidence in the court system. ${ }^{14}$ Overall, greater uniformity always leads to promotion of legal certainty. ${ }^{15}$ Finally, advanced expertise is probable to enhance the efficiency of the judiciary and attain better case management. ${ }^{16}$ Specialist judge is expected to deal with cases more efficiently and more expeditiously due to the much greater frequency in adjudicating certain type of cases. Developing routines, the greater familiarity and versatility to its tasks leads to streamlined operations and more efficient processing of cases. By repeating similar tasks, the specialist judge is likely to develop expertise to adjudicate disputes in more efficient and timely manner. ${ }^{17}$ Regarding the case management, judicial specialization is considered as a factor for fostering efficiency in allocation of cases since diverting a certain type of cases to specialized court divisions or specialized courts can increase the overall efficiency of the justice system, especially when the courts of general jurisdiction are overburdened by growing caseloads. ${ }^{18}$

Although, the value of judicial specialization per se is not being questioned since it is certain that it can produce positive effects in terms of achieving greater efficiency of the processing of cases, there are certain issues indicating that specialization itself can have potential drawbacks that can produce negative impact on the proper administration of justice.

In its Opinion (2012) no. 15, the CCJE asserts a relatively long list of potential risks of judicial specialization. The following issues are being identified as pos-

Zimmer M., Overview of Specialized Courts, International Journal for Court Administration, August 2009, Vol. 2, Issue 1, p. 2.

13 Para 9 of the Opinion (2012) no. 15 of the CCJE on the Specialisation of Judges adopted at the 13th plenary meeting of the CCJE (Paris, 5-6 November 2012).

14 See Gramckow H.; Walsh B., Developing Specialized Court Services, International Experiences and Lessons Learned, Justice and Development Working Paper Series, World Bank, 2013, p. 6.

15 Para 10 of the Opinion (2012) no. 15 of the CCJE on the Specialisation of Judges adopted at the 13th plenary meeting of the CCJE (Paris, 5-6 November 2012).

16 Para 13 of the Opinion (2012) no. 15 of the CCJE on the Specialisation of Judges adopted at the 13th plenary meeting of the CCJE (Paris, 5-6 November 2012).

17 See Zimmer, op. cit., note 12, p. 1, Gramckow; Walsh, op. cit., note 14, p. 6, Baum, op. cit., note 4, p. 1676.

18 Silvestri E., Judicial Specialization: In Search of the 'Right' Judge for Each Case, Russian Law Journal, Vol. II, Issue 4, 014, p. 168. 
sible minuses: 1. possible separation of specialist judges from the general body of judges; 2. impeding the evolution of case law since specialist judges might tend to reproduce previous decisions; 3. compartmentalisation of law and procedure which could weaken the principle of legal certainty; 4. undermining necessary versatility of judicial work; 5 . risk to the unity of the judiciary since the specialist judges can get the impression that they are some kind of elite, which can negatively affect the public confidence in generalist judges; 6 . potential exposure of judges to increased pressure from parties, interest groups and state authorities; 7. risk of excessive proximity between judges, lawyers and prosecutors due to frequent formal or informal contacts; 8. potential inequalities in access to justice due to concentration of jurisdiction on one or several courts which can also create excessive distance between the judge and the litigant; 9. potential violation of the right to be heard since the specialist judge may tend to consult or advise his colleagues from the bench without presenting the matters to the parties; and 10. risk of inequality among courts and judges regarding material and human resources. ${ }^{19}$

Also, the inability of the judge to see the 'big picture' could also be listed as drawback among the other issues. Namely, if the focus is set predominantly on a certain specific and narrow field, it is expected that the judge will develop a narrow or even one-sided view of issues that will sometimes compromise the quality of decisions since he would be unable to incorporate his expertise into the larger framework that needs to be taken into account for an optimal solution. His decision might be flawless in respect of the area of law he is specialized with, but flawed in terms of broader settings of the case in regard to different areas that are beyond his own specialty but are relevant for reaching a rightful decision. ${ }^{20}$

One of the biggest concerns of the potential risks of judicial specialization seems to be its possible interference with the classic values of impartiality and independence of the judge. The specialist judge must meet the requirements of impartiality and independence as his generalist peer. The 'randomness principle' in allocating cases among generalist judges who are supposed to be equally qualified to hear and decide particular case, so it is irrelevant which judges does so, seems to enhance the public confidence in the impartial administration of justice. Random allocation of cases rather than by reference to judicial expertise or preference is always perceived as an ally of the principle of judicial impartiality. ${ }^{21}$

19 Para $14-23$ of the Opinion (2012) no. 15 of the CCJE on the Specialisation of Judges adopted at the 13th plenary meeting of the CCJE (Paris, 5-6 November 2012).

20 Silvestri, op. cit., note 18, p. 168.

${ }_{21}$ Mack K.; Roach Anleu S.; Wallace A., Caseload Allocation and Special Judicial Skills: Finding the 'Right' Judge?, International Journal for Court Administration, Vol. 4, Issue 3, December 2012, p. 1. 
The key question that arises from the analysis of the pro et con of judicial specialization is whether the specialization of judges appears to be preferable in the context of promoting the proper administration of justice. Studies that have been carried out to identify the impact of specialization show that specialization can enhance the efficiency of procedure and quality and timeliness of decision-making. Still, the potential drawbacks must be taken into serious consideration regarding the overall impact of specialization on the functioning of the system of administration of justice. In that regard, the CCJE stresses out that judicial specialization is justified only if it promotes the administration of justice, i.e. if it proves preferable in order to ensure the quality of proceedings and decisions. ${ }^{22}$ It is certain that specific level of in depth knowledge and expertise is preferable in areas of law that are considered as time-consuming, problematic and complex. Still, all judges, regardless if they are considered as generalist or specialist must be experts in the art of judging, must meet the requirements of independence and impartiality and must be of equal status. ${ }^{23}$

Other question that also draws attention is in which areas of law the judicial specialization is considered as most desirable and justified. How do we recognize what is a complex legal and factual setting that needs an extra expertise in order to reach a quality decision? Which criteria should we use to differentiate 'ordinary' cases from 'complicated' ones, the ones that are considered to be better handled by a specialist judge? This issues endure especially given the fact that the area of civil law covers matters that are usually specific and ask a certain level of expertise. The strict adherence towards judicial specialisation brings the risk of unnecessary multiplication of number of specialized courts although there is no rationale for such thing. ${ }^{24}$

\section{REVITALIZATION OF “MUTUAL TRUST”}

Mutual trust stands in the center of the whole EU legal system and it is the basis upon which all of its modalities are functioning. ${ }^{25}$ This position of mutual trust has been acknowledged by the CJEU in Opinion 2/13 on the Accession of the EU to the European Convention on Human Rights where it was stated that the principle of mutual trust is at the heart of the EU and a "fundamental premise" of the Eu-

22 Para 38 of the Opinion (2012) no. 15 of the CCJE on the Specialisation of Judges adopted at the 13th plenary meeting of the CCJE (Paris, 5-6 November 2012).

23 Conclusions of the Opinion (2012) no. 15 of the CCJE on the Specialisation of Judges adopted at the 13th plenary meeting of the CCJE (Paris, 5-6 November 2012).

24 See also Silvestri, op. cit., note 18, p. 167.

25 European Commission, Press Release 'Building Trust in Justice Systems in Europe: 'Assises de la Justice' Forum to Shape the Future of EU Justice Policy', 21 November 2013. 
ropean legal structure. ${ }^{26}$ The European Commission has stated that 'mutual trust is cornerstone of judicial co-operation in the EU'. ${ }^{27}$ Even the European Court of $\mathrm{Hu}$ man Rights (ECtHR) has reassured this position where it is stated that the Brussels regime in the EU 'is based on the principle of 'mutual trust in the administration of justice' in the European Union'. ${ }^{28}$ Recognition and enforcement of foreign decisions in the EU represents one of the legal areas where the principle of 'mutual trust' is very important and in these filed the principle of "mutual trust" is manifested through the principle of 'mutual recognition'. This idea is not something new, since it was present in the very first EU cross-border recognition and enforcement instruments where it was considered that exequatur should be based on the principle of mutual 'confidence'. ${ }^{29}$ From this point, "mutual confidence" as principle has evolved as the 'principle of mutual trust' which is precondition for mutual recondition in the single market. ${ }^{30}$ In this modality, the principle of "mutual trust" is acknowledged as the basis for the functioning of the EU and regarding recognition and enforcement of foreign judicial decisions it has been manifested as mutual recognition. ${ }^{31}$

The central component of the free circulation of judgments in the EU is the 'mutual recognition'. ${ }^{32}$ Often "mutual trust" and "mutual recognition" are considered to be synonyms, however this assumption is neither correct, nor precise. Mutual recognition of judgments is a goal, an objective, ${ }^{33}$ while the principle of mutual recognition is a legal principle of $\mathrm{EU} \mathrm{law}^{34}$ and a fundamental principle in judicial cooperation in civil and criminal matters. ${ }^{35}$ In essence mutual trust contains an obligation of all the authorities of a Member State to trust the authorities of the other Member State

$26 \quad$ See Opinion 2/13, ECLI:EU:C:2014:2454, para.168 and 169.

27 European Commission, Press Release 'Towards a true European area of Justice: Strengthening trust, mobility and growth', 11 March 2014.

28 Avotinš v Latvia, app. no. 17502/07, para. 49.

29 Report on the Convention on jurisdiction and the enforcement of judgments in civil and commercial matters (Signed at Brussels, 27 September 1968) by Mr P. Jenard, Official Journal of the European Communities No. C 59/1, p. 46-47.

30 Completing the Internal Market, White Paper from the Commission of the European Communities to the European Council, COM (85) 310 final, Brussels, 14.06.1985, para.93.

31 Wischmeyer, T., Generating Trust Through Law? - Judicial Cooperation in the European Union and the 'Principle of Mutual Trust', 17 German L. J., 2016 p. 351.

32 Mutual recognition plays important role also in other EU legal fields, see Kramer, X., Cross-Border Enforcement in the EU: Mutual Trust versus Fair Trial? Towards Principles of European Civil Procedure, International Journal of Procedural Law, 2011, p. 209.

33 Arenas García R., Abolition of Exequatur: Problems and Solutions - Mutual Recognition, Mutual Trust and Recognition of Foreign Judgments: Too Many Words in the Sea, Yearbook of Private International Law, 2010 , p. 362.

34 C-120/79 Rewe-Zentral AG v Bundesmonopolverwaltung für Branntwein [1980] ECR 00731.

35 Kramer, op. cit., note 32, p. 209. 
and therefore to assume their decisions $s^{36}$ and with that it builds a true European judicial area. ${ }^{37}$ As a consequence mutual trust is a factual and political ground for the implementation of mutual recognition which leads to directly proportional nexus: when mutual trust exists, mutual recognition should be improved. ${ }^{38}$

Free circulation of judgments within the EU it was implemented for the first time in the Council Regulation (EC) No 2201/2003 of 27 November 2003 concerning jurisdiction and the recognition and enforcement of judgments in matrimonial matters and the matters of parental responsibility, repealing Regulation (EC) No 1347/2000 (Brussels IIbis Regulation) ${ }^{39}$ for certain cases of child abduction and access rights. Similar tendencies are followed in several other EU instruments such as Regulation (EU) No 1215/2012 of the European Parliament and of the Council of 12 December 2012 on jurisdiction and the recognition and enforcement of judgments in civil and commercial matters (Regulation Brussels Ibis) and Council Regulation (EU) 2019/1111 of 25 June 2019 on jurisdiction, the recognition and enforcement of decisions in matrimonial matters and the matters of parental responsibility, and on international child abduction (Regulation 1111/2019) ${ }^{40}$. The construct of the idea of free circulation of judgments is based upon 'mutual trust' and 'mutual recognition'. Theoretically, increased 'trust' between the Member States lowers the need for the 'control' in essence exequatur represents. The directly proportional formula stands: 'mutual trust' improves the procedures for recognition and enforcement. However, 'trust' as it was defined by Luhmann ${ }^{41}$ requires direct assurance (confidence in one's own expectation) that the other person behaves accordingly (actual trust). In terms of the mutual trust in the EU, this represents imposed 'trust', a political decision that Member States can have confidence in the political assessment of the EU institutions that other Member States' behaviors are satisfying expectations. As such, mutual trust in terms of EU is 'indirect trust' gained through the assessment of the EU institutions. This can produce undesired effects of circumvention of the application of the Brussels IIbis Regulation regarding 'mutual recognition'. 42

\footnotetext{
36 Arenas García, op.cit. note 33, p. 375.

37 European Council, 'The Stockholm Programme - An open and secure Europe serving and protecting the citizens' (Official Journal of the European Union, C 115 2010) 11.

38 Arenas García, op.cit. note 33, p. 362.

39 OJ L 338, 23.12.2003, p. 1-29.

40 OJ L 178, 2.7.2019, p. 1-115.

41 Luhmann N., Vertrauen, Frankfurt, $4^{\text {th }}$ ed, 2000, p.1, (translated by Weller, M., Mutual Trust: In Search of the Future of European Private International Law, Journal of Private International Law, Issue 1, 2015, p. 68.

42 For more on the effectiveness of "mutual trust" see Misoski, B., Rumenov, I.. The Effectiveness of Mutual Trust in Civil and Criminal Law in the EU, EU and Comparative Law Issues and Challenges Series
} 
Therefore, in view of enforcement of judicial decisions in the EU, a question of balance between the 'trust and 'control' stands. The EU regarding the abolition of exequatur in Brussels Ibis Regulation, made a certain compromise, by keeping the control but in a later stage. 'Control' was taken in the form that the ex ante control by the state now is transformed to ex post control initiated by the parties. So the abolition of the exequatur in the Brussels regime represents moving the coordination to a later stage of the implementation of recognition and enforcement. ${ }^{43}$

In context to the importance of the 'mutual trust' regarding the family law matters with cross-border implications, the Regulation 1111/2019 unambiguously highlighted that the EU has set an objective of creating, maintaining and developing an area of freedom, security and justice, in which the free movement of persons and access to justice are ensured ${ }^{44}$ and in that manner the rights of persons, in particular children, in legal procedures should be reinforced in order to facilitate the cooperation of judicial and administrative authorities and the enforcement of decisions in family law matters with cross-border implications. ${ }^{45}$ This is particularly important because of the smooth and correct functioning of a EU area of justice with respect for the Member States' different legal systems and traditions. In the background of these processes is the 'mutual trust' manifested through three basic principles: enhanced 'mutual recognition' of civil decisions, simplified access to justice and improved exchanges of information between the authorities of the Member States. ${ }^{46}$ This means that for the Member States to institutionally and legally effectuate the 'mutual trust' the authorities should communicate directly building trust among themselves, provide for procedures that facilitate the access to justice and keep the grounds for non-recognition to the minimum in the light of the underlying aim of the Regulation which is to facilitate recognition and enforcement and to effectively protect the best interests of the child. ${ }^{47}$ In comparison with its predecessor, the Regulation 2201/2003, the new recast goes into more details, effectuating the three principles upon which 'mutual trust' should be achieved. For example, direct Court communication in the Regulation 2201/2003 was mentioned only in relation with communication between the Courts when issuing a non-return order (Article 11(6)) and the Article 15 (Transfer to a court better placed to hear the case) while in the Regulation 1111/2019

(ECLIC), Vol. 1, 2018, pp.364-390.

43 See Section 3 of the Brussels Ibis Regulation. On the practical application of the Brussels Ibis Regulation see, Kramer X., et others, The application of Brussels I (Recast) in the legal practice of EU Member States Synthesis Report, Asser Institute and Erasmus University Rotterdam, 2016, p. 1-56.

44 Recital (3) of the Regulation 1111/2019.

45 Ibid.

46 Ibid.

47 Recital (55) of the Regulation 1111/2019. 
it is general rule that the courts can cooperate and communicate directly with, or request information directly from, each other provided that such communication respects the procedural rights of the parties to the proceedings and the confidentiality of information. ${ }^{48}$

\section{SPECIALIZATION OF JURISDICTION AS A MODALITY FOR IMPROVEMENT OF "MUTUAL TRUST"}

One of the examples for the Member States how to abide the propositions for enhancing 'mutual trust' regarding the cross-border family law relations, determined in the Regulation $1111 / 2019$ is the modality of the specialization of the jurisdiction, provided in the form of concentration of jurisdiction. ${ }^{49}$ This idea of providing for specialization of jurisdiction in the judicial cooperation in civil matters in the EU is not a novelty, but it has been gradually developed in accordance with the EU legal sources and the jurisprudence of the CJEU. The quest of finding balance between territoriality and functionality principles in the EU has not been exclusive only for family law matters ${ }^{50}$ and expands to other legal fields such as maintenance relations,$^{51}$ consumer contracts ${ }^{52}$ and regarding European Account Preservation Order (EAPO)..$^{53}$ The rationale for this approach is that although the Brussels jurisdictional regime and the regimes under the other Regulations provide for compete and closed set of jurisdiction rules, designed to grant jurisdiction to the court best qualified to ensure respect for the best interest of the child and/ or sound administration of justice, ${ }^{54}$ in certain situations the traditional rules of

48 See in comparison Article 55 and 56 of the Regulation 2201/2003 and Article 86 of the Regulation $1111 / 2019$.

49 Recital (41) of the Regulation 1111/2019.

50 C-498/14 PPU David Bradbrooke v Anna Aleksandrowicz, ECLI:EU:C:2015:3.

51 Joined Cases C-400/13 and C-408/13, Sophia Marie Nicole Sanders, represented by Ms Marianne Sanders, v. David Verhaegen (C-400/13), and Barbara Huber v. Manfred Huber (C-408/13), ECLI:EU:C:2014:2461.

52 Case C-498/16, Maximilian Schrems v. Facebook Ireland Limited, ECLI:EU:C:2018:37.

53 For more on the reforms regarding the specialization of jurisdiction in cases concerning EAPO see the Finnish, Austrian, Slovakian and the newest Czech experience. Carlos Santaló Goris, A centralized court for the EAPO Regulation in the Czech Republic? conflictoflaws.net [https://conflictoflaws.net/2021/acentralized-court-for-the-eapo-regulation-in-the-czech-republic] Accessed 18 April 2021.

54 Recital (12-13) of the Brussels IIbis Regulation, Recital (15) of the Council Regulation (EC) No 4/2009 of 18 December 2008 on jurisdiction, applicable law, recognition and enforcement of decisions and cooperation in matters relating to maintenance obligations, OJ L 7, 10.1.2009, p. 1-79 (Maintenance Regulation) and Recital (16) of the Brussels I Regulation. 
jurisdiction can be abandoned and rules on concertation of jurisdiction can be integrated in order to facilitate access to justice. ${ }^{55}$

The categorization of the EU legal instruments provides for more specific overview of the principles according to which the specialization can be achieved and the modalities that can be applied, based on their protective aim and purpose: first group of EU legal instruments that relate to private international law and civil procedure in the field of cross-border civil and commercial matters which provide protection of economic interest of the parties, and second group of EU legal instruments in the field of cross-border family law matters whose specific nature requires special social protection. ${ }^{56}$ Both of these groups are basing their possible specialization on different aims: the first group aiming to achieve more cost-effective proceedings and enhance legal certainty, while the latter group intending to enable specialized courts to have greater expertise to conduct the proceedings especially those involving children and minors. ${ }^{57}$

The situation with the Regulation 1111/2019 in correlation with the specialization of jurisdiction is particularly interesting. Concentrated jurisdiction is not provided in the operative part of the Regulation, rather it is proposed as a suggestion or principle which should improve access to justice especially in the cases that relate to the mixed child abduction regime established by the Regulation $1111 / 2019$ and the 1980 Hague Convention of on the Civil Aspects of International Child Abduction. ${ }^{58}$ The Regulation 1111/2019 adds another factor that goes in line of the general aims of the concentration of jurisdiction, that is the enhancement of the effectiveness of the procedure and the promptness of all of the measures taken by the relevant authorities in situations of wrongful removal or retention. Also such reasoning has been developed and affirmed by the CJEU in regard to maintenance relations, where in case C-400/13, the CJEU stated that:

"...a centralization of jurisdiction, such as that at issue in the main proceedings, promotes the development of specific expertise, of such a kind as to improve the effectiveness of recovery of maintenance claims, while ensuring the proper administration of justice and serving the interests of the parties to the dispute." 59

In Regulation 1111/2019 this reasoning was explicitly explained that:

\footnotetext{
55 Župan, M.; Poretti, P. Concentration of Jurisdiction - Is Functionality of Judiciary Becoming an Obstacle to Access to Justice?, EU and comparative law issues and challenges series (ECLIC), Vol. 3, 2019, p. 320.

56 Ibid.

57 Ibid.

58 Internal organization of the judiciary is not in domain of the EU competences nor its regulatory activity. See, Župan; Poretti, op.cit., note 9, p. 357.

59 C-400/13, Sanders and Huber, 18 December 2014, ECLI:EU:C:2014:2461, para. 45.
} 
"In order to conclude the return proceedings under the 1980 Hague Convention as quickly as possible, Member States should, in coherence with their national court structure, consider concentrating jurisdiction for those proceedings upon as limited a number of courts as possible. Jurisdiction for child abduction cases could be concentrated in one single court for the whole country or in a limited number of courts, using, for example, the number of appellate courts as point of departure and concentrating jurisdiction for international child abduction cases upon one court of first instance within each district of a court of appeal."

Child abduction cases represent prototype for concentration of jurisdiction ${ }^{60}$ because of two factors: first, the judge should adjudicate very promptly in the proposed timeframe within 6 weeks ${ }^{61}$ and secondly for the judge to be able to take all of the measures provided in the 1980 Hague Convention certain knowledge and expertise is necessary. ${ }^{62}$ In the EU, this complex and particularly delicate procedure for the return of the wrongfully removed or retained children is further complicated with the interplay between the Regulation 1111/2019 and the 1980 Hague Convention. ${ }^{63}$ Such position directly refers to the issue of mutual trust and mutual recognition, because of the possibility of reevaluation of the decisions by the Court of the habitual residence of the child with a goal that this court should be the final arbitrator of the child's future. ${ }^{64}$ Additionally, this system is positioned in a way not to encroach upon the parties' procedural rights or interests by discouraging the abducting parent from challenging a non-return order in the Member State where the child is actually present and that the left-behind parent will normally be the best placed to present his or her arguments before the courts of the Member State of habitual residence. ${ }^{65}$ Such structure is based on the mutual recognition principle, where the custody decisions (containing a return of the child), which fulfill the necessary conditions and are in the proper form, can be certified and can be directly enforceable in all Member States without formal application for recognition and without any possibility of recognition being

60 Župan; Poretti, op.cit., note 9, p. 346.

61 Article 11 of the 1980 Hague Convention.

62 Župan; Poretti, op.cit., note 9, p. 346.

63 Article 96 of the Regulation 1111/2019 "Where a child has been wrongfully removed to, or is being wrongfully retained in, a Member State other than the Member State where the child was habitually resident immediately before the wrongful removal or retention, the provisions of the 1980 Hague Convention shall continue to apply as complemented by the provisions of Chapters III and VI of this Regulation. Where a decision ordering the return of the child pursuant to the 1980 Hague Convention which was given in a Member State has to be recognized and enforced in another Member State following a further wrongful removal or retention of the child, Chapter IV shall apply".

64 McEleavy P., The new child abduction regime in the European Union: Symbiotic relationship or forced partnership? Journal of Private International Law, Issue 17, 2005, p. 34.

65 Case C-195/08 PPU Inga Rinau [2008] ECR I-05271 Opinion of AG Sharpston delivered on 1 July 2008 para 80. 
refused. ${ }^{66} \mathrm{~A}$ removal of a child to another Member State has therefore no effect on the decision of the court of origin. ${ }^{67}$ The final decision on the child wellbeing is positioned at the Court in the Member State where the child was habitually resident immediately before the wrongful removal or retention and this Court has already been seized of proceedings to examine the substance of rights of custody, or within three months of the notification of a decision for non-return of the child based on Articles 13(1)(b) and 13(2) of the 1980 Hague Convention, one of the parties seizes a court in the Member State where the child was habitually resident immediately before the wrongful removal or retention in order for the court to examine the substance of rights of custody. ${ }^{68}$

The system which was established with the Brussels IIbis Regulation and the position of the abolishment of the exequatur represented manifestation of the concept of 'mutual recognition' and reflected the integration and the trust that exists in the European Judicial Area. ${ }^{69}$ There are two main justifications for this policy: the economical and the political. ${ }^{70}$ In the first case, the abolition of the exequatur increases the economic welfare of the European economic actors and citizens. ${ }^{71}$ In the second case, 'mutual recognition' exists to ensure that judgments circulate freely within the European Union. ${ }^{72}$ For civil and commercial aspects, the fulfillment of these goals brings certainty and efficiency. ${ }^{73}$ Such rationales in the cases of child abduction are problematic. Firstly, the timeframe for return of the wrongfully removed and retained children to their habitual residence is very narrow. This mechanism is centered around the premise that the Courts and the Central Authorities cooperate among themselves. In complex situations as child abduction cases are, there are multiple legal acts that need to be taken into consideration

66 Article 29(6) of the Regulation 1111/2019.

67 See, Article 29(6) of the Regulation 1111/2019 in conjunction with Chapter IV Section 2 regarding recognition and enforcement of certain privileged decisions.

68 Article 29(3) and Article 29(5) of the Regulation 1111/2019. However, Regulation 1111/2019 provides for possibility of refusing the recognition and enforcement of decisions issued in accordance with Article 29(6) of the Regulation 1111/2019, on the grounds that decision shall be refused if and to the extent that it is irreconcilable with a later decision relating to parental responsibility concerning the same child which was given: (a) in the Member State in which recognition is invoked; or (b) in another Member State or in the non-Member State of the habitual residence of the child provided that the later decision fulfils the conditions necessary for its recognition in the Member State in which the recognition is invoked (Article 50 of the Regulation 1111/2019).

69 McEleavy, op.cit., note 64, p. 32.

70 Cuniberti G.; Rueda I., Abolition of Exequatur. Addressing the Commission's Concerns, Rabels Zeitschrift, 2011, p. 286-316 (31).

$71 \quad$ Ibid. p. 291.

72 Ibid.

73 McEleavy, op.cit., note 64, p. 32. 
- Brussels IIbis Regulation, 1980 Hague Convention and the vast number of case law surrounding these legal sources. This certainly provides problems in the proper application of provisions in such short timeframe.

So for these problems, the concentration of jurisdiction does not represent the "magic potion" that solves all of the above described problems. Regulation $1111 / 2019$ tries to provide for one certain step into the right direction, by very carefully suggesting solution for building actual trust in the cases of the child abduction because the internal organization of the judiciary is not in domain of the EU competences nor its regulatory activity. ${ }^{74}$ However, the experience with the implementation of the 1980 Hague Child Abduction Convention has shown that specialized jurisdiction has indeed improved its application and is in line with the more expeditious procedure required for the return of the wrongfully removed or retained children. ${ }^{75}$ Bulgaria has conducted a double concentration - first to a single court (Sofia Regional Court) and second to a specialized section of the court (family law section) which has proven successful. ${ }^{76}$ Germany has boosted the promptness of the procedure on $43 \%$ of the return application resolved in the six week timeframe when implemented the concentration of the jurisdiction from 620 family courts to only 24 family courts. ${ }^{77}$ Finally the example of Netherlands shows that the concentration of the jurisdiction form 19 District Courts to one District Court in the Hague, reduced the length of the procedure from 18 months to a period of six weeks or less. ${ }^{78}$ Such effects of the reduction of the delay in the proceedings, provides for better use of the resources for training and implementation of mediation in these cases, ${ }^{79}$ which provides for greater expertise and builds actual trust which is essential in the development of "mutual trust" between the relevant authorities. .

\section{MACEDONIAN PERSPECTIVE ON JUDICIAL SPECIALIZATION}

There is no unified or universal approach that can be followed in organizing the judiciary when specialization is set as a key principle. Also, there is no international standard that strictly proposes or disapproves the notion of judicial special-

\footnotetext{
$74 \quad$ Župan; Poretti, op.cit., note 9, p. 357.

75 Lee Ho, K., The Need for Concentrated Jurisdiction in Handling Parental Child Abduction Cases in the United States, Santa Clara Journal of International Law, Vol.14, Issue 2, 2016, p. 614.

76 Lee Ho, op.cit., note 75, p. 609.

77 Ibid.

78 Ibid.

79 Ibid.
} 
ization or the method how such specialization should be implemented. Since the judicial specialization can be interpreted from different perspectives, the specific local circumstances and the particular needs of the system of administration of justice play a key role in that regard. Due to the fact that judicial specialization can take various forms, its implementation in the judicial system can be carried out through different models: 1 . establishment of separate specialized courts; 2 . formation of separate specialized divisions in the court of general jurisdiction; and 3. specializing judges in certain area of law to process cases that require particular expertise that a court may occasionally receive..$^{80}$

The organization of the Macedonian judiciary is regulated by the Law on Courts. ${ }^{81}$ According to its provisions, our judicial system accepts the division of jurisdiction between courts of general jurisdiction and specialized courts, although these terms are not explicitly used in the Law. The concept of specialized courts is limited to the establishment of separate administrative courts. The Law on Courts explicitly states that principally the work in the courts is performed in specialized court divisions. The specialized court divisions are established depending on the type and scope of work in the court, particularly in the area of criminal law, juvenile delinquency, civil law, commercial law, labour disputes and for other types of disputes that fall within the competence of the court. ${ }^{82}$ As for the specialization of judges, it is carried out within the specialized court divisions. As a general rule, the judge is elected to adjudicate in certain respective areas of law. The allocation of judges in certain court divisions is performed through the annual work schedule determined by the president of the court upon previously obtained opinion from the session of judges, i.e. the general session of the Supreme Court of N. Macedonia taking into account the determination of the judge for specialization in criminal, civil, commercial, administrative and other legal field. The judge may not be transferred from one court division to another without his/her consent. ${ }^{83}$

Given the aforementioned provisions, it follows that all the matters that fall within the scope of civil justice are adjudicated by courts of general jurisdiction. ${ }^{84}$ Re-

80 For further details on the models of specialization see Gramckow; Walsh, op. cit., note 14, p. 10-12.

81 In the judicial system, judicial power is exercised by the primary courts, the appellate courts, the Administrative Court, the Higher Administrative Court and the Supreme Court of the Republic of Macedonia (Art. 22 of Law on Courts, Official Gazette of RM No. 58/06, 62/06, 35/08, 150/10, 83/18, 198/18 and Official Gazette of RNM No. 96/19).

82 A special court division is established in the court if more than five judges adjudicate that particular type of cases (Art. 66 para. 3 of the Court Rules).

83 See Art. 12 and Art. 39 of Law on Courts.

84 Regarding the primary courts, they are established for one or more municipalities. There are a total of 27 primary courts in N. Macedonia. Competentia ratione materiae of the primary courts is determined by the rules of general legal delegation. The primary courts are established as courts with basic 
garding judicial specialization in the sphere of adjudicating civil and commercial matters, the judiciary is organized by accepting the model of establishment of specialized court divisions. ${ }^{85}$

If we make a retrospective of the organization of Macedonian judiciary in terms of specialization regarding adjudication in civil and commercial matters, it can be noticed that the current approach with the sole acceptance of the model of specialized court divisions wasn't always the case and that Macedonia had a relatively long tradition of existence of specialized courts. Namely, for almost fifty years, firstly as a republic in the federal system of Yugoslavia and afterwards as an independent country, Macedonia was familiar with the model of specialized courts regarding adjudication in commercial disputes. The establishment of commercial courts was part of the judicial reform carried out in 1954. Until 1954 the adjudication of commercial disputes was in the competence of the state arbitration. Commercial courts were established as regular courts that had jurisdiction to adjudicate certain types of disputes and perform other tasks within the competence of the regular courts that require specific (specialized) expertise of judges and other judicial stuff. Regarding its structure, they were organized in two stages, as district commercial courts and the Commercial court of Macedonia. ${ }^{86}$ Commercial courts were abolished with the Law on Courts from 1995. ${ }^{87}$ Although the exact reasons for its abolishment remains unclear, it is assumed that the main impetus for such reform step was the rationalization of the organization of the judiciary and concentration and allocation of human, financial and materiel resources in the courts of general jurisdiction. Given the fact that the organization of first instance courts of general

jurisdiction and courts with extended jurisdiction. Within primary courts with extended jurisdiction, establishment of specialized court divisions that will adjudicate certain types of cases is obligatory. It should be noted that although all the primary courts are established as courts of general jurisdiction, the Law on Courts established a different ratione materiae jurisdiction of the primary courts for the area of Skopje as the capital city. Namely, the two primary courts that are situated in Skopje are organized as 'specialized' courts with complete separation of jurisdiction in criminal and civil matters. Previously known as Primary Court Skopje 1 and Primary Court Skopje 2, the primary courts in Skopje are now renamed as Primary Criminal Court Skopje and Primary Civil Court Skopje.

85 For example, in the Primary Civil Court Skopje the organization of the separate special divisions is as follows: according to the annual work schedule of the Court, the judges are deployed in four divisions: 1 . division for property disputes, family disputes and small claims disputes; 2 . division for labor disputes; 3. division for non-contentious civil procedure and probate procedure; and 4. division for commercial disputes, bankruptcy and liquidation.

86 For the territory of Macedonia, there were three district commercial courts. For further details, see Georgievski S., Marina P. Matovski N., Judiciary System of SFRJ, 1983, p. 105 et seq, Georgievski S., Judiciary in Republic of Macedonia, Yearbook of the Faculty of Law in Skopje, Vol. XXXIV, 1990/1991, p. 43-46.

87 According to the Law on Courts from 1995, the commercial courts ceased to operate on July 30, 1996. See Art. 111 of Law on Courts 1995 (Official Gazette of RM No. 36/95, 45/95, 64/2003). 
jurisdiction was structured through the principle of general legal delegation, with establishment of specialized court divisions for certain areas of law, it was expected that such judicial organization would fulfil the requirements of efficient, professional and competent judiciary. ${ }^{88}$

\subsection{Specialization of jurisdiction regarding child abduction cases in $\mathbf{N}$. Macedonia}

The child abduction cases represent very delicate and important cases because of the irreversible harm that can be conducted upon the wrongfully removed or retained children which are unilaterally relocated from their familiar environment and displaced in different place from their habitual residence. Usually, these cases are resolved before a judicial authority, ${ }^{89}$ but the 1980 Hague Convention refers directly to both procedures, ${ }^{90}$ administrative and judicial, thus leaving to the contracting party to determine the type of procedure that will apply regarding these type of cases. The procedure for the return of the wrongful removed or retained children in accordance to the 1980 Hague Convention in N. Macedonia is envisaged as administrative procedure. ${ }^{11}$ The Centre for Social Work is the authority which decides about the return of abducted children, while the Central Authority

88 It was assumed that within the system of courts of general jurisdiction there are organizational and functional possibilities for rational use of the professional potential of the courts, as well as previous professional experience. In simple terms, the concentration of jurisdiction in first instance courts of general jurisdiction was seen as a factor of quality, rationality and economy in the adjudication process. It was considered that the acceptance of the concept of general court system without the existence of specialized courts will establish the judiciary as an extraordinarily clear and productive organization without dissipating of the competencies of different courts and their interference. See Dimiškovski D., On Macedonian Judiciary (1995-2000), Skopje, 2003.

89 Lee Ho, op.cit., note 75, p. 609; Duraković A.; Meškić Z., Operation of the Hague Child Abduction Convention in Bosnia and Herzegovina, in Župan, M., (ed.), Private International Law in the Jurisprudence of European Courts - Family at Focus, Pravni fakultet Osjek, 2015, p. 213; Župan M.; Hoško T., Operation of the Hague Child Abduction Convention in Croatia, in Župan, M. (ed.), Private International Law in the Jurisprudence of European Courts - Family at Focus, Pravni fakultet Osjek, 2015, p. 227; Kostić-Mandić M., Country Report on Application of the Hague Child Abduction Convention - Montenegro, in Župan, M. (ed.), Private International Law in the Jurisprudence of European Courts - Family at Focus, Pravni fakultet Osjek, 2015, p. 253; Marjanović S., Some Open Issues in the Application of the 1980 Hague Child Abduction Convention in the Republic of Serbia, in Župan, M. (ed.), Private International Law in the Jurisprudence of European Courts - Family at Focus, Pravni fakultet Osjek, 2015; Kraljić S., Operation of the Hague Child Abduction Convention in Slovenia, in Župan, M. (ed.), Private International Law in the Jurisprudence of European Courts - Family at Focus, Pravni fakultet Osjek, 2015, p. 279.

90 See for example, Articles 11-18 of the 1980 Hague Convention.

91 Rumenov I., Application of the Hague Child Abduction Convention in Macedonia, in Župan, M. (ed.), Private International Law in the Jurisprudence of European Courts - Family at Focus, Pravni fakultet Osjek, 2015, p. 247. 
is seated within the Ministry of Labour and Social Policy of the Republic of N. Macedonia. ${ }^{92}$ The communication between the relevant authorities in the Republic of N. Macedonia is conducted promptly, however, they have not been able to abide the timeframes of the HC $1980 .{ }^{93}$ The length of the procedure is between six and twelve weeks, although in some cases it can be longer than that. In addition, there is no concentrated jurisdiction. All of the 29 Community Centres for Social Work can decide on a return order. They are coordinated by 16 Intercommunity Centres for Social Work. The procedure is administrative and the administrative authorities directly apply the HC $1980 .{ }^{94}$ In some situations, when the outcome was predictable, the parents would often come to an agreement about the return. In these situations, the Central Authority and administrative authority did not receive information whether the child was returned or not, so these cases are unaccounted. Another concerning circumstance is when, in the finishing stages of a return procedure, rather than issuing a (non-)return order, the relevant authorities and the Central Authority would simply inform the other central authority via e-mail that the child would not be returned to the place of his/her habitual residence. ${ }^{95}$ In light of the mentioned circumstances, the statistical data regarding the child abduction cases vary because of the unaccounted cases. For example, in the period from 2008-2014 there are 32 applications, out of which 28 are regarding return of wrongfully removed or retained child and 5 applications are regarding access rights. ${ }^{96}$ In 2013 there were 12 applications out of which 8 were decided and 4 were pending. ${ }^{97}$

It is certain that some degree of specialization in regard to the complex child abduction cases is required. Firstly, N. Macedonia should seriously reconsider the position of the child abduction cases from administrative to judicial procedure. Secondly, from the experience of the judicial specialization in the EU and in the region there are several possible solutions that can be applied, but for proper functioning and effect of the applied modality, notion has to be given to the characteristics of the Macedonian judiciary. The proposed model in the Regulation $1111 / 2019$ to consider concentrating jurisdiction for child abduction cases upon as limited number of courts as possible and that jurisdiction for child abduction cases could be concentrated in one single court for the whole country or in a lim-

\footnotetext{
92 Rumenov op.cit., note 91,p. 243.

$93 \quad$ Ibid., p. 245.

$94 \quad$ Ibid., p. 247.

95 Ibid.

96 Ibid., p. 245.

97 The inconsistency in the statistical data is because the Central Authority does not possess any software programme for processing, documenting and/or archiving application files (relevant documentation) and cases are processed in hard copy. Ibid., p. 245.
} 
ited number of courts, using, for example, the number of appellate courts as point of departure and concentrating jurisdiction for international child abduction cases upon one court of first instance within each district of a court of appeal. Moreover, the Bulgarian experience in these cases of a double concentration seems efficient - first to a single court (Sofia Regional Court) and second to a specialized section of the court (family law section). ${ }^{98}$ Their experience shows that not only territorial concentration is desirable but also it provides for more attentive and experienced judges in the field of cross border family law to render more effective and well-founded decisions. It is therefore preferable that N. Macedonia should follow these concepts and implement more attentive and assiduous approach in assuring that the unilateral measures taken by the parent which wrongfully removed or retained the child from its habitual residence are not the final arbiter, instead the best interest of the child assured by the closest forum to the child and that is the Court where the child had his habitual residence before the abduction, maintains its jurisdiction to finalize these delicate cases in regard to the custody rights.

\section{CONCLUSION}

The extent of judicial specialization through different models of its implementation in the national judicial systems worldwide increases over time due to the fact that the law is becoming more complex and specific in certain fields. In that regard, specific level of in depth knowledge and expertise always seems preferable in areas of law that are considered as time-consuming, problematic and complex. Specialization is firmly linked to the organization of a particular judicial system and no universal approach exists in organizing the judiciary when specialization is set in the focus of the judicial reform. Additionally, no international standard endures in terms of strictly proposing or disapproving the judicial specialization or the method how such specialization should be carried out. The particular needs for an efficient system of administration of justice that will ensure the quality of the proceedings and decisions, as well as the specific local circumstances are of significant importance in that respect. The experience of the EU in the construction of the "mutual trust" in light of the child abduction cases gives an insight of the construction of "mutual trust" in the whole EU. This is something that is not achievable as a political decision because trust is generally social construct deeply rooted in the interconnection of humans. Most of the organized systems such as the economical, legal and religious systems are constructed on the basis of "trust" which is practically implemented by the persons which are inside these systems. This is also applicable in regard to the principle of mutual trust in the EU. If

$98 \quad$ Lee Ho, op.cit., note 75, p. 609. 
this principle operates practically, then trust in the whole system is achievable. If mutual recognition is operating in the EU without legal circumvention, then actual trust emerges. Specialization of jurisdiction is more than welcomed solution, especially in complex cases which need to be conducted promptly and very assiduously, such as the child abduction cases. Building mutual trust between the relevant authorities that implement the 1980 Hague Convention not only does provide for political points for the operation of the area of freedom, security and justice, in which the free movement of persons and access to justice are ensured, but also helps in the development of a save environment for children in which the legal system guarantees their wellbeing and proper development as functioning part of our society.

The position of the child abduction cases in N. Macedonia shows that there is certain room for improvement of the implementation of the 1980 Hague Convention. Moreover, N. Macedonia is a candidate country to the EU and is required to follow the EU acquis communautaire. Specialization of jurisdiction is not directly part of these EU legal sources, however the requirement of a functioning legal system that assures access to justice and further enhances free movement of people is. In the cases of child abduction, these freedoms are directly under attack, because a wrongfully removed or retained child is exactly an example of limited freedom for developing normal relations between child and a parent. In this light, N. Macedonia should further consider firstly to transfer the procedure from administrative to judicial and secondly to consider for some model of specialization of jurisdiction in this type of cases with notion to the characteristics of the Macedonian judiciary.

\section{REFERENCES}

\section{BOOKS AND ARTICLES}

1. Arenas García R., Abolition of Exequatur: Problems and Solutions - Mutual Recognition, Mutual Trust and Recognition of Foreign Judgments: Too Many Words in the Sea, Yearbook of Private International Law, 2010, 351-376

2. Baum L., Judicial Specialization and the Adjudication of Immigration Cases, 59(8) Duke Law Journal 1501, 2010, 1501-1561

3. Baum L., Judicial Specialization, Litigant Influence, and Substantive Policy: The Court of Customs and Patent Appeals, 11 Law \& Society Review 823, 1977, 823-850

4. Baum L., Probing Effects of Judicial Specialization, 58(7) Duke Law Journal 1667, 2009, 1667-1684

5. Cuniberti G.; Rueda I., Abolition of Exequatur. Addressing the Commission's Concerns, Rabels Zeitschrift, 2011, 286-316

6. Dimiškovski D., On Macedonian Judiciary (1995-2000), Skopje, 2003 
7. Duraković A.; Meškić Z., Operation of the Hague Child Abduction Convention in Bosnia and Herzegovina, in Župan, M. (ed.), Private International Law in the Jurisprudence of European Courts - Family at Focus, Pravni fakultet Osjek, 2015, 213-227

8. Georgievski S., Judiciary in Republic of Macedonia, Yearbook of the Faculty of Law in Skopje, Vol. XXXIV, 1990/1991, 38-47

9. Georgievski S.; Marina P.; Matovski N., Judiciary System of SFRJ, 1983

10. Gramckow H.; Walsh B., Developing Specialized Court Services, International Experiences and Lessons Learned, Justice and Development Working Paper Series, World Bank, 2013

11. Kostić-Mandić M., Country Report on Application of the Hague Child Abduction ConventionMontenegro, in Župan, M. (ed.), Private International Law in the Jurisprudence of European Courts - Family at Focus, Pravni fakultet Osjek, 2015, 251-259

12. Kraljić S., Operation of the Hague Child Abduction Convention in Slovenia, in Župan, M. (ed.), Private International Law in the Jurisprudence of European Courts - Family at Focus, Pravni fakultet Osjek, 2015, 275-283

13. Kramer X., et others, The application of Brussels I (Recast) in the legal practice of EU Member States Synthesis Report, Asser Institute and Erasmus University Rotterdam, 2016;

14. Kramer, X., Cross-Border Enforcement in the EU: Mutual Trust versus Fair Trial? Towards Principles of European Civil Procedure, International Journal of Procedural Law, 2011, 202-230

15. Lee Ho, K., The Need for Concentrated Jurisdiction in Handling Parental Child Abduction Cases in the United States, Santa Clara Journal of International Law, Vol.14, Issue 2, 2016, 596-614

16. Luhmann N., Vertrauen, Frankfurt, $4^{\text {th }}$ ed, 2000, p.1, (translated by Weller, M., Mutual Trust: In Search of the Future of European Private International Law, Journal of Private International Law, Issue 1, 2015, 68-81

17. Mack K.; Roach Anleu S.; Wallace A., Caseload Allocation and Special Judicial Skills: Finding the 'Right' Judge?, International Journal for Court Administration, Vol. 4, Issue 3, December 2012, 1-14

18. Mak E., Balancing Territoriality and Functionality; Specialization as a Tool for Reforming Jurisdiction in the Netherlands, France and Germany, International Journal for Court Administration, Vol. 1, Issue 2, October 2008, 1-8

19. Marjanović S., Some Open Issues in the Application of the 1980 Hague Child Abduction Convention in the Republic of Serbia,, in Župan, M. (ed.), Private International Law in the Jurisprudence of European Courts - Family at Focus, Pravni fakultet Osjek, 2015, 259-275

20. McEleavy P., The new child abduction regime in the European Union: Symbiotic relationship or forced partnership? Journal of Private International Law, Issue 17, 2005, 5-34

21. Misoski, B.; Rumenov, I.. The Effectiveness of Mutual Trust in Civil and Criminal Law in the EU, EU and Comparative Law Issues and Challenges Series (ECLIC), Vol. 1, 2018, 364-390

22. Rumenov I., Application of the Hague Child Abduction Convention in Macedonia, in Župan, M. (ed.), Private International Law in the Jurisprudence of European Courts - Family at Focus, Pravni fakultet Osjek, 2015, 243-251 
23. Silvestri E., Judicial Specialization: In Search of the 'Right' Judge for Each Case, Russian Law Journal, Vol. II, Issue 4, 2014, 165-175

24. Uzelac A., Mixed Blessing of Judicial Specialsation: The Devil is in the Detail, Russian Law Journal, Vol. II, Issue 4, 2014, 146-164

25. Wischmeyer, T., Generating Trust Through Law? - Judicial Cooperation in the European Union and the 'Principle of Mutual Trust', 17 German L. J., 2016, 339-382

26. Zimmer M., Overview of Specialized Courts, International Journal for Court Administration, Vol. 2, Issue 1, August 2009, 1-15

27. Župan M.; Hoško T., Operation of the Hague Child Abduction Convention in Croatia, in Župan, M. (ed.), Private International Law in the Jurisprudence of European Courts - Family at Focus, Pravni fakultet Osjek, 2015, 227-242

28. Župan M.; Poretti P., Concentration of Jurisdiction in Cross-Border Family Matters - Child Abduction Cases in Vinković M. (ed.), New Developments in EU Labour, equality and human rights law, Pravni fakultet Osjek, 2015, 341-357

29. Župan, M.; Poretti, P. Concentration of Jurisdiction - Is Functionality of Judiciary Becoming an Obstacle to Access to Justice?, EU and comparative law issues and challenges series (ECLIC), Vol. 3, 2019, 297-323

\section{EU LAW}

1. Completing the Internal Market, White Paper from the Commission of the European Communities to the European Council, COM (85) 310 final, Brussels, 14.06.1985

2. Council Regulation (EC) No 2201/2003 of 27 November 2003 concerning jurisdiction and the recognition and enforcement of judgments in matrimonial matters and the matters of parental responsibility, repealing Regulation (EC) No 1347/2000, OJ L 338, 23.12.2003

3. Council Regulation (EC) No 4/2009 of 18 December 2008 on jurisdiction, applicable law, recognition and enforcement of decisions and cooperation in matters relating to maintenance obligations, OJ L 7, 10.1.2009

4. Council Regulation (EU) 2019/1111 of 25 June 2019 on jurisdiction, the recognition and enforcement of decisions in matrimonial matters and the matters of parental responsibility, and on international child abduction, OJ L 178, 2.7.2019

5. European Commission, Press Release 'Building Trust in Justice Systems in Europe: 'Assises de la Justice' Forum to Shape the Future of EU Justice Policy', 21 November 2013

6. European Commission, Press Release 'Towards a true European area of Justice: Strengthening trust, mobility and growth', 11 March 2014

7. European Council, 'The Stockholm Programme - An open and secure Europe serving and protecting the citizens' (Official Journal of the European Union, C 115 2010) 11

8. Regulation (EU) No 1215/2012 of the European Parliament and of the Council of 12 December 2012 on jurisdiction and the recognition and enforcement of judgments in civil and commercial matters, OJ L 351, 20.12.2012

9. Report on the Convention on jurisdiction and the enforcement of judgments in civil and commercial matters (Signed at Brussels, 27 September 1968) by Mr P. Jenard, Official Journal of the European Communities No. C 59/1 


\section{INTERNATIONAL AGREEMENTS AND OTHER DOCUMENTS}

1. Hague Convention of on the Civil Aspects of International Child Abduction of 25 October 1980

2. Opinion (2012) no. 15 of the Consultative Council of European Judges (CCJE) on the Specialisation of Judges adopted at the 13th plenary meeting of the CCJE (Paris, 5-6 November 2012)

\section{LIST OF NATIONAL REGULATIONS, ACTS AND COURT DECISIONS}

1. Avotiņš v Latvia, app. no. 17502/07

2. C-120/79 Rewe-Zentral AGv Bundesmonopolverwaltung für Branntwein [1980] ECR 00731

3. C-400/13, Sanders and Huber, 18 December 2014, ECLI:EU:C:2014:2461

4. C-498/14 PPU David Bradbrooke v Anna Aleksandrowicz, ECLI:EU:C:2015:3

5. Case C-195/08 PPU Inga Rinau [2008] ECR I-05271 Opinion of AG Sharpston delivered on 1 July 2008

6. Case C-498/16, Maximilian Schrems v. Facebook Ireland Limited, ECLI:EU:C:2018:37

7. Law on Courts 1995 (Official Gazette of RM No. 36/95, 45/95, 64/2003)

8. Law on Courts, Official Gazette of RM No. 58/06, 62/06, 35/08, 150/10, 83/18, 198/18 and Official Gazette of RNM No. 96/19)

9. Joined Cases C-400/13 and C-408/13, Sophia Marie Nicole Sanders, represented by Ms Marianne Sanders, v. David Verhaegen (C-400/13), and Barbara Huber v. Manfred Huber (C-408/13), ECLI:EU:C:2014:2461 